\title{
Omani Consumer's Ethnocentrism and Demand for Locally Produced Products
}

\author{
Msafiri Daudi Mbaga1*, Lamya Salim Khamis Al Abri², Shekar Bose1, Houcine Boughanmi1 \\ ${ }^{1}$ Natural Resource Economics, College of Agriculture and Marine Sciences, Sultan Qaboos University, Muscat, Oman \\ ${ }^{2}$ Ministry of Agriculture and Fisheries Wealth, Muscat, Oman \\ Email: ^msafiri@squ.edu.om, lamya_505@hotmail.com, sbose@squ.edu.om,boughanh@squ.edu.om
}

How to cite this paper: Mbaga, M.D., Al Abri, L.S.K., Bose, S. and Boughanmi, H. (2018) Omani Consumer's Ethnocentrism and Demand for Locally Produced Products. American Journal of Industrial and Business Management, 8, 1440-1459. https://doi.org/10.4236/ajibm.2018.86097

Received: March 26, 2018

Accepted: June 8, 2018

Published: June 11, 2018

Copyright $\odot 2018$ by authors and Scientific Research Publishing Inc. This work is licensed under the Creative Commons Attribution International License (CC BY 4.0).

http://creativecommons.org/licenses/by/4.0/

\begin{abstract}
The continued spread of globalization has resulted in levels of global product availability that is not only unprecedented, but would have been regarded as impossible not too long ago. Products of almost every conceivable national origin (both industrial and fresh agricultural products) are now widely available throughout the world. Because the "country of origin" (COO) label of a product is a factor that in many cases influences the buying behavior of consumers, government policy makers and businesses know that they need to investigate consumer attitudes toward both domestic and imported products and the findings of these investigations need to be used to formulate more effective national "buy local" campaigns and marketing strategies. This issue has never been important in Oman than it is now when the country has embarked on strategies to diversify the economy. The success of the diversification strategies by the Oman government would, among other things, depend on the success of the promotion of "locally produced" products. Therefore, investigating and understanding consumer attitudes toward both domestic and imported products becomes important. This study intends to do just that by investigating consumer ethnocentrism of Omanis.
\end{abstract}

\section{Keywords}

Consumer Ethnocentrism, CETSCALE, Marketing, Locally Produced Products

\section{Introduction}

Due to the increased trend of globalisation of business environment, consumers are increasingly exposed to and are selecting from a considerable selection of imported commodities and brands than ever before [1] [2]. Consequently, deci- 
sion-making by consumers in markets worldwide has become progressively more complex across all categories of consumption. This has led to a growing need for businesses and governments to understand the dynamics that affect consumers' evaluations of both locally produced and imported commodities.

Furthermore, this has also led to a growing interest in the effects of country-of-origin on consumers' beliefs and buying behaviour [3] [4].

To entice consumers into viewing locally produced products positively against imported products, governments and businesses have known to engage in targeted "buy local" campaigns. Campaigns targeting and encouraging consumers to buy locally produced products are therefore nowadays widespread. The buy locally-produced foods campaign generally hinges, among other things, on the belief that locally produced foods are environmentally friendly, healthy and support local businesses and jobs.

In Oman, for example, there is the "Origin Oman" which is a domestic campaign to promote Oman produced products and services. At the market place therefore, Oman consumers are faced with a choice between locally-produced products (supported and promoted by the "Origin Oman" campaign) and imported products. In this context, therefore the issue of the Country of Origin (hereafter, COO) and hence the Country of Origin Effect (hereafter, COOE) comes into play. To understand the implications of $\mathrm{COO}$ and hence the COOE, we need to look at the consumer decision making process.

Usually consumers make decisions about the quality of products based on a systematic process of acquisition, evaluation and integration of product information or cues [5]. A cue is defined as all informational stimuli available to the consumer before consumption [6], and can be intrinsic or extrinsic. Examples of intrinsic cues are taste and design, while extrinsic cues include COO, brand, and price [7]. When intrinsic cues are missing or cannot easily be assessed, consumers tend to rely more on extrinsic cues [8]. This is often the case for food products (such as beef, chicken and vegetables) since the cost of searching for intrinsic cues to aid consumers in product evaluation far exceeds the benefits [9].

There is therefore a perceived association between $\mathrm{COO}$ and product quality [1] and as a result, consumers use $\mathrm{COO}$ to infer the quality of products.

One of the factors which may influence a consumer's decision to buy a locally-produced rather than a foreign-produced product is the concept of Consumer Ethnocentrism [10]. The concept of consumer ethnocentrism, according to [11], arose from the more general concept of ethnocentrism introduced by [12]. According to [12], ethnocentrism represents feelings of superiority for one's group and all things related to it. The originator of the concept of Consumer Ethnocentrism is [13]. According to [13], consumer ethnocentrism is the belief held by consumers about the appropriateness and morality of purchasing foreign-made products. For ethnocentric consumers, purchasing imported products is seen as immoral and unpatriotic, because it has an adverse impact on the domestic economy. Hence ethnocentric consumers tend to purchase locally-produced 
products even if the quality is lower than that of imported-products [14]. To non-ethnocentric consumers, on the other hand, imported-products are objects to be evaluated on their own merits.

Therefore, where consumer ethnocentrism is strong, consumers take $\mathrm{COO}$ into consideration when evaluating products and the "Buy Local" campaigns tend to succeed.

The primary purpose of this study is to investigate consumer ethnocentrism of Omanis and the effect of it on consumer demand for locally-produced products. The specific objective of this study is therefore three folds: first, to investigate the extent of consumer's ethnocentrism in Oman; second, to investigate the relationship between ethnocentrism of Omani consumers and their attitudes toward "locally-produced products; third, to evaluate Omani consumers' views towards "Buy Locally-Produced Products campaign". The rest of this study is organized as follows. Section two provides a review of selected literature on the subject matter of this study. Section three presents the research methodology. Section four is a discussion of results. Section five summarizes findings of the study, draws conclusions and highlights the implications of this study.

\section{Literature Review}

Consumer attitude and preferences toward different products has been recognized in international marketing literature for over three decades [1] [15]. Much of modern-day economic, consumer and marketing research is based on the proposition that consumers perceive products as conveying a collection of information signals to potential buyers [16].

These information signals can be intrinsic (such as taste, design, fit and performance) or extrinsic (such as color, price, brand name, packaging and warranty) [17]. In practice, it may be difficult for a consumer to interpret intrinsic signals prior to the purchase of a commodity. Therefore in most cases consumers often resort to using extrinsic signals as the basis on which to make inferences about products.

Several studies have shown that consumers were consistently biased towards products originating from certain countries. In terms of the level of economic development there seems to be a relationship between COO effects and the level of economic development. Products from developing countries are rated as inferior to products from developed countries [18] and [19].

Furthermore, literature shows that consumers in some countries, especially developed countries, generally assess products from their own country more favourably than products from other countries, while consumers from less-developed countries seem to evaluate imported products from more developed countries more favourably than domestically produced products. From the large number of $\mathrm{COO}$ studies to date, there seems to be clear evidence that a product's $\mathrm{COO}$ has an effect on different aspects of consumer evaluation and choice behavior [20]. 
However, beyond the evidence of a generalized $\mathrm{COO}$ effect, some consumers have shown systematic bias in favour of domestically produced products at the expense of comparable products from foreign countries. According to [10] and [21], such preferences could be expressions of a more widespread and general concept, termed "Consumer Ethnocentrism".

The construct of Consumer Ethnocentrism is often confused with "COO bias", but actually the two are distinct and independent of each other [22]. An example to explain the difference was provided by [23] who argued that an American consumer could have a positive $\mathrm{COO}$ attitude towards a French product for its product-class attributes, but could decide not to buy the product for nationalistic reasons. Consumer Ethnocentrism can therefore be regarded as a "general tendency" to avoid buying foreign products as opposed to a specific $\mathrm{COO}$ image. Furthermore, $\mathrm{COO}$ effect represents the cognitive and emotional aspects of the consumer decision-making process, while Consumer Ethnocentrism refers to the emotional and normative aspects of buyer behaviour. This normative dimension is regarded as a unique aspect of consumer ethnocentrism.

According to [24], the term ethnocentrism was defined by [12] as "The view of things in which one's own group is the centre of everything, and all others are scaled and rated with reference to it".

According to [25] an ethnocentric individual strongly supports the traditions, symbols, icons, and products of his or her own culture and that such a person simultaneously dislikes the traditions, symbols, icons and products of other cultures. However, ethnocentric individuals over time develop perceptions of other cultures and these perceptions form a basis for comparing products of other countries with those from their own country. Ethnocentrism can therefore be regarded as a learned behaviour, forming part of an individual's socialisation. It was in the late 1980s that the concept of ethnocentrism was extended to the consumer behaviour domain by [13] and at that point the term "Consumer Ethnocentrism" was born.

Based on [13], Consumer Ethnocentrism provides individuals with a sense of identity, feelings of "belongingness" and an understanding of which kind of purchase behavior is deemed to be acceptable or not to the in-group. An individual's consumer ethnocentric tendencies may under certain circumstances be expected to influence attitudes and behavior in favor of foreign products, and against competitive domestic products [26].

Consumer Ethnocentrism is one of the most researched variables moderating the COO effect. In fact, according to [27] researching on the Consumer Ethnocentrism construct is a vital step towards a better understanding of the way individual and organisational consumers compare domestic and foreign products, as well as the reasons why patriotic prejudices are developed about foreign products. With respect to this, it is widely speculated that, along with increased nationalism as well as a heavy emphasis on cultural and ethnic identity, the construct of Consumer Ethnocentrism will continue to be a powerful force in the 
future global business environment [2].

Given the significance of the Consumer Ethnocentrism construct for both local and international business environment, measuring the level of Consumer Ethnocentrism becomes of interest. For example, [28] contend that measuring the level of Consumer Ethnocentrism within and across countries can be of particular interest to both local and multinational marketers, as it may pose a barrier to possible success in local and foreign markets. Knowledge of the level of consumer ethnocentrism may also be useful for the development of product-positioning strategies in foreign markets and could help explain bias towards domestic products.

An instrument called the CETSCALE (The Consumer Ethnocentric Tendency Scale) to measure the ethnocentric tendencies of consumers was developed by [13]. The CETSCALE is a 17-item questionnaire using either a seven or five Likert-type scale.

[13] applied the CETSCALE instrument to more than 800 US consumers; the results indicated that consumers' general attitudes toward foreign products had a strong negative correlation with ethnocentric tendencies. The stronger the ethnocentric bias of a consumer, the more likely he or she would buy a domestic product and/or the stronger the intention to buy a domestic product would be.

Over the years the reliability and validity of the CETSCALE have been tested all over the world and the CETSCALE has been found to have a high degree of validity and reliability [29]. Examples of these studies include studies conducted with samples from Japan and West Germany [28] France [30] Malta [31] Korea [26] Poland [32] [33] Russia [34] Turkey [1] [2] Spain [27] Australia [21] Czech Republic [29] Israel [35] Canada [34] Ghana [36] and Turkey [37]. Over time, shorter versions of the CETSCALE, based on the original 17-item scale, were developed. For example there is the 10-item version of the CETSCALE also developed by [13]. The 10-item version of the CETSCALE was used by [38] [39] and [11]. However, to date the original 17-item scale CETSCALE remains the most popularly used scale in many studies. According to [40], the total possible score that can be recorded with the 17-item CETSCALE ranges between 17 and 119 (with mean $=68$ ), based on the use of a seven-point Likert-type scale. And the range is between 17 and 85 (with mean $=51$ ) based on the use of a 5-point Likert-type scale. The mean scale value of the CETSCALE is used as an indicator of the level of Consumer Ethnocentrism, with higher mean scale values indicating higher levels of consumer ethnocentrism.

Since its development, the CETSCALE, has been translated and used to assess consumer ethnocentrism in a number of countries outside the US [39]. Results indicate that Consumer Ethnocentrism is not necessarily a phenomenon of the developed world. Studies conducted on consumers in countries with emerging economies have revealed mean scale values comparable to the mean scale values of consumers from developed countries, suggesting that consumers from developing countries will not necessarily buy foreign products instead of domestic 
products. As is the case with the current study, the primary issue of interest to Consumer Ethnocentrism researchers is whether consumer ethnocentrism increases the demand and hence sales of domestic products over imported products [22]. Studies investigating the correlation between consumer attitudes towards the importation of products and the construct of consumer ethnocentrism have consistently revealed that the more ethnocentric a consumer is, the more the consumer will be opposed to the importation of foreign goods [30] [36] and [41].

Aside from this general conclusion, [26] identified two factors that seem to have a moderating effect on ethnocentric tendencies of consumers.

The first factor is the perceived product necessity. When a product is perceived as a necessity, Consumer Ethnocentrism has a relatively small influence on consumers' attitudes towards importing that product. For products that are perceived as nonessential however, Consumer Ethnocentrism should have a more substantial impact on the attitudes of consumers towards the importation of those products.

The second factor is the perceived economic threat, [26] hypothesised that the impact that consumer ethnocentric tendencies have on consumers' attitudes towards the importing of products is moderated by the perceived threat of foreign competition. The attitudes of consumers, primarily towards products perceived as either posing a personal threat to individuals or the domestic economy, should therefore be strongly influenced by consumer ethnocentricity. Ethnocentric tendencies of consumers have increased impact on consumers' resistance to importing products that are perceived as threatening to their personal or domestic economic welfare.

Of interest to the current study is the usefulness of the Consumer Ethnocentric construct in evaluating and explaining the success of the "Buy Local Campaigns." The word "locally" in our case refers to-those food commodities that are grown, or produced and sold within the country. This is the definition that has been used by others such as [42]. In today's food markets, consumers are increasingly interested in "locally produced" food products because they are perceived to provide several benefits: higher food quality; increase social and economic justice; higher environmental sustainability (including the minimization of food miles, the use of sustainable production methods [43]. Having developed the CETSCALE which is an instrument to measure the ethnocentric tendencies of consumers, [13] called upon researchers to test the CETSCALE in other countries and other ethnic groups. This study is therefore an attempt to heed the call by [13], as well as, to add into the literature on consumer willingness to pay premium for locally produced products.

\section{Research Methodology}

Based on the research objectives of this study, there are three research questions to be dealt with in this study, and the questions are as follows: 
1) What is the level of Consumer Ethnocentrism in Oman?

2) What is the relationship between ethnocentrism of Omani consumers and their attitudes toward "locally grown" defined here as Omani grown/ Omani produced products.

3) What are the Omani consumers' attitudes towards "Buy Locally-Produced Products campaign?"

To answer research questions one, two and three, this study will employ the CETSCALE and attitudinal statements. The CETSCALE and the instruments have been used previously by other researchers notably [13] [36] [41] [44] [45] and [46].

The CETSCALE is a 17-item questionnaire; see Table 1, developed by [13] to measure consumer ethnocentrism using either a 7 point Likert-type scale $(1=$ Strongly Disagree, 2 = Disagree, $3=$ Disagree Somewhat, $4=$ Neither agree nor disagree (Neutral (Undecided)), $5=$ Agree Somewhat, $6=$ Agree, and $7=$ Strongly

Table 1. CETSCALE questions to address the first research question. For each of the following statements that comprise the CETSCALE, respondents were asked to rate them using a 5 -point scale $(1=$ Strongly Disagree, $2=$ Disagree, $3=$ Neither agree nor disagree (Neutral), $4=$ Agree, and 5 = Strongly Agree) .

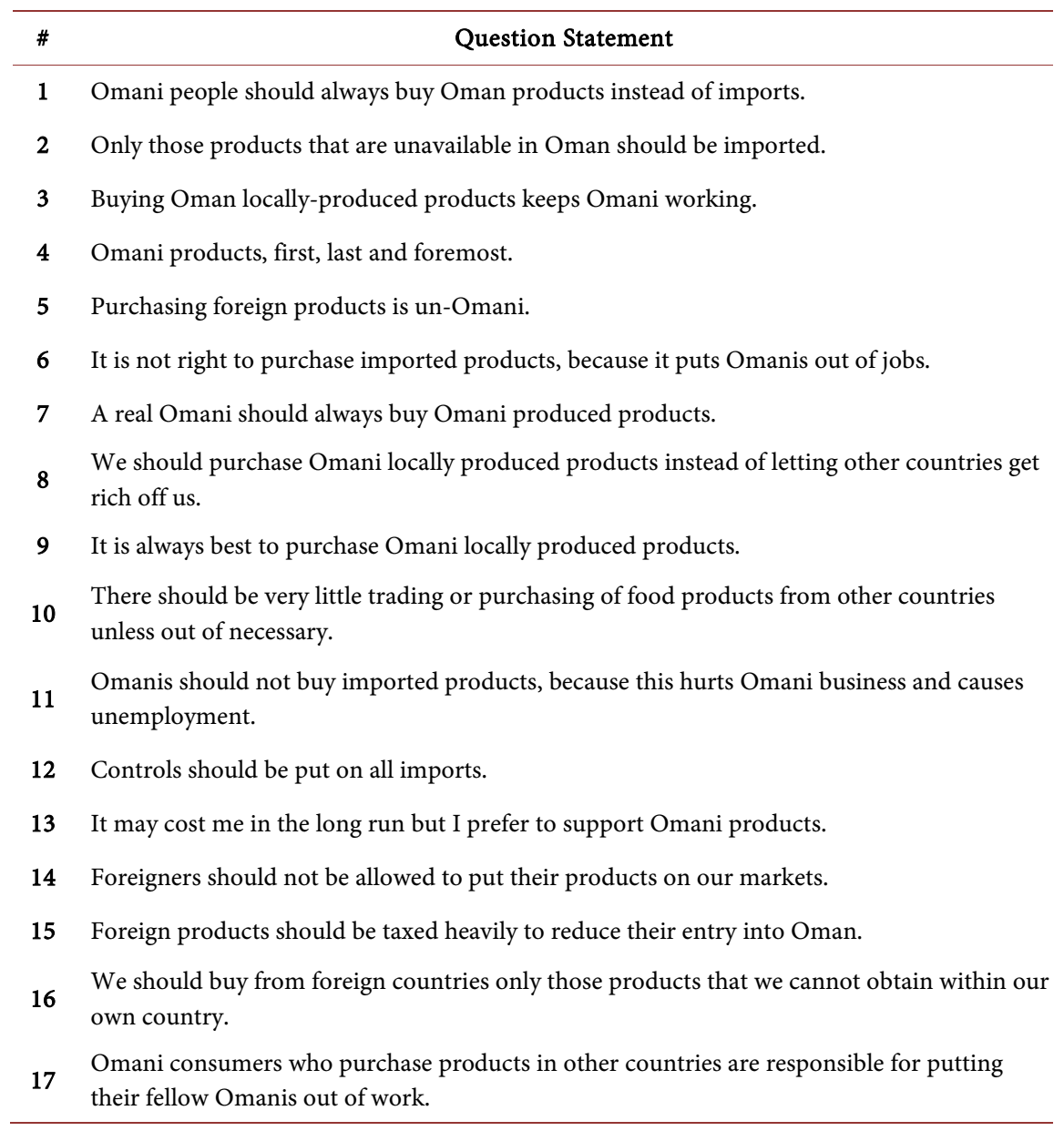

Note: Products for the purpose of this research means: Beef, Chicken and vegetables represented by tomatoes and cucumbers. 
Strongly Agree $)$ or a 5 point Likert-type scale $(1=$ Strongly Disagree, $2=$ Disagree, 3 = Neither agree nor disagree (Neutral), $4=$ Agree, and $5=$ Strongly Agree).

Justification for using the scale is based on confirmation of its reliability and validity by a number of researchers [23] [26] [27] [28] [36] [41] [44]-[49]. According to [40], the total possible score that can be recorded with the 17 -item CETSCALE ranges between 17 and 119 (with mean $=68$ ), based on the use of a seven-point Likert-type scale. And the range is between 17 and 85 (with mean = 51) based on the use of a 5-point Likert-type scale. The mean scale value of the CETSCALE is used as an indicator of the level of Consumer Ethnocentrism

As reported by [47], high CETSCALE scores (above 68 for a 7-point Likert-type scale and above 51 for a 5-point Likert-type scale) indicate a high level of ethnocentrism, while low CETSCALE scores (below 68 for a 7-point Likert-type scale and below 51 for a 5-point Likert-type scale) indicate a low level of ethnocentrism. Attitudinal scales developed and tested by [50] and employed in [36] have been utilized in this study to address the second and third research questions.

According to these researchers the attitudinal scales establishes a link between the country-of-origin effect and the general purchasing behavior of consumers. Following [36] and [50], the same attitudinal statements will be employed in this study with a 5 -point Likert-type scale, $(1=$ Strongly Disagree, $2=$ Disagree, $3=$ neither agree nor disagree (Neutral (Undecided)), $4=$ Agree, and $5=$ Strongly Agree). The attitudinal statements are intended to solicit the opinions of Omani consumers, first about Oman produced products (Table 2), and then secondly about "Buy Locally-produced products" campaign (Table 3 ).

\section{Data Collection and Sample Description}

Data was collected by means of a questionnaire developed based on a review of key literatures [13] [21] [36] and [41].

Table 2. Consumer attitudes towards Omani Locally Produced Products-to address the second research question. For each of the following statements, respondents were asked to rate them using a 5-point scale $(1=$ Strongly Disagree, $2=$ Disagree, $3=$ Neither agree nor disagree (Neutral), $4=$ Agree, and $5=$ Strongly Agree) .

\begin{tabular}{ll}
\hline$\#$ & \multicolumn{1}{c}{ Attitudinal Statement } \\
\hline $\mathbf{1}$ & Omani locally produced products are generally of poorer quality than imported products \\
2 & Omani locally produced products are generally higher-priced than imported products \\
3 & $\begin{array}{l}\text { I buy Omani locally produced products wherever possible } \\
\text { These days I usually look for Omani locally produced food products when I am shopping for } \\
\text { food }\end{array}$ \\
5 & $\begin{array}{l}\text { People should buy food products which offer them the best value-for-money, whether made } \\
\text { in Oman or not }\end{array}$ \\
& $\begin{array}{l}\text { People should choose the Omani locally produced food products when the price and quality } \\
\text { are as good as imported food products }\end{array}$ \\
\hline
\end{tabular}

Note: Products for the purpose of this research means: Beef, Chicken and vegetables represented by tomatoes and cucumbers. 
Table 3. Consumer Attitudes towards "Origin Oman" or "Buy Local" campaign to address the third research question. For each of the following statements, respondents were asked to rate them using a 5 -point scale $(1=$ Strongly Disagree, $2=$ Disagree, $3=$ Neither agree nor disagree (Neutral), $4=$ Agree, and $5=$ Strongly Agree) .

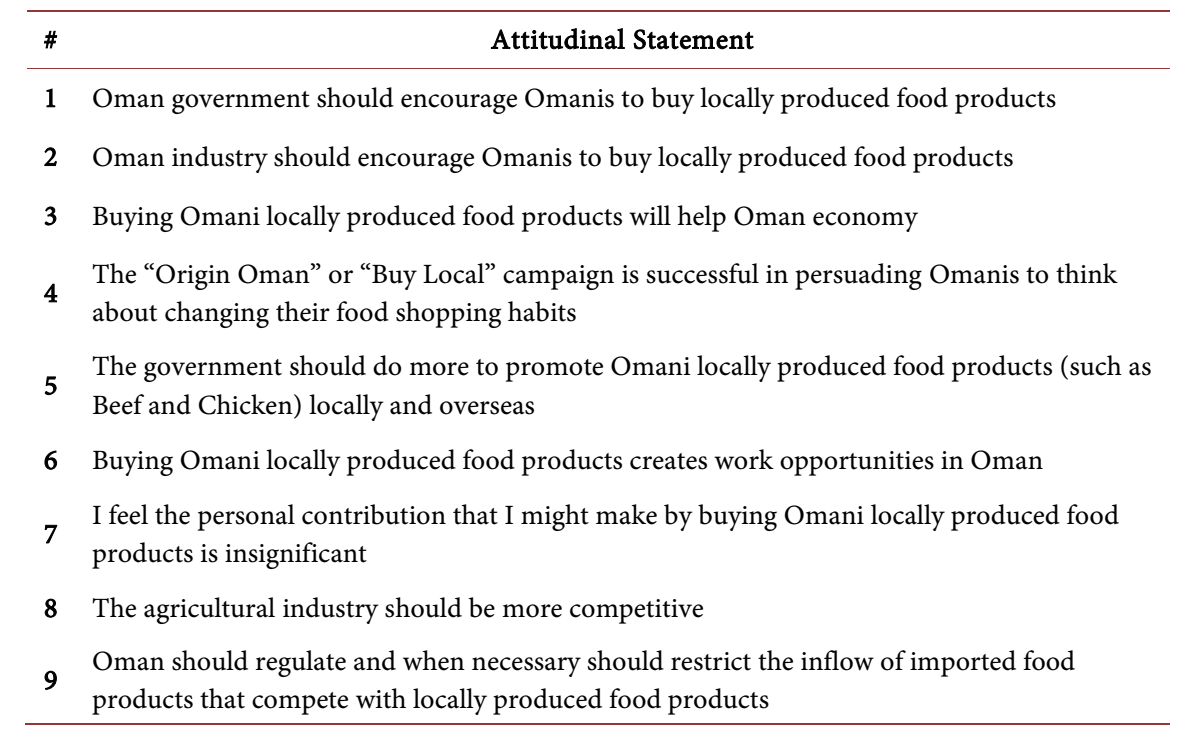

Note: Products for the purpose of this research means: Beef, Chicken and vegetables represented by tomatoes and cucumbers.

The mall intercept approach was used to collect data in the study. The validity of mall intercept is supported by other studies [36] and [51].

A total of 450 respondent shoppers were interviewed. Forty five (45) questionnaires were found unusable, as a result, were discarded and the remaining 405 were used in this study. The socio-economic and demographic characteristic of respondents is presented in Table 4. The sample was comprised of mostly Omani at $91.1 \%$. Males and females were 59 and $41 \%$ respectively. The majority of respondents (91.8\%) are relatively young between 20 and 50 years old and $67.4 \%$ have College Diploma and above. Income wise 39.3\% reported income between 601 and 1000 Rial Oman per month (1 Rial Oman $=2.59$ US\$).

\section{Empirical Results and Discussion}

\subsection{Research Question One}

CETSCALE scores were computed for each respondent. The mean, the standard deviation, the minimum, the maximum and the median were found to be: 56.96, 12.1, 27, 85 and 57 respectively. The CETSCALE questions along with the mean and standard deviation for each question are presented in Table 5 below.

According to [13], the mean ethnocentrism value indicates the strength of ethnocentrism. A higher mean value indicates higher consumer ethnocentrism, while lower mean value implies lower ethnocentrism. The CETSCALE mean value of 56.96 (Table 5) shows that Omani consumers in the study are ethnocentric.

Omani consumers can be described as ethnocentric since the mean score 
Table 4. Socio-economic and Demographic Characteristics $(n=405)$.

\begin{tabular}{|c|c|c|}
\hline Characteristics & Frequency & Percentage \\
\hline \multicolumn{3}{|l|}{ Nationality } \\
\hline Omani & 369 & 91.1 \\
\hline \multirow[t]{2}{*}{ Non-Omani } & 36 & 8.9 \\
\hline & & 100.0 \\
\hline \multicolumn{3}{|l|}{ Gender } \\
\hline Male & 239 & 59.0 \\
\hline \multirow[t]{2}{*}{ Female } & 166 & 41.0 \\
\hline & & 100.0 \\
\hline \multicolumn{3}{|l|}{ Marital status } \\
\hline Single & 109 & 27.0 \\
\hline \multirow[t]{2}{*}{ Married } & 296 & 73.0 \\
\hline & & 100.0 \\
\hline \multicolumn{3}{|l|}{ Age } \\
\hline Under 20 & 4 & 1.0 \\
\hline 20 to 30 years & 147 & 36.3 \\
\hline 31 to 40 years & 135 & 33.3 \\
\hline 41 to 50 years & 90 & 22.2 \\
\hline \multirow[t]{2}{*}{50 years and above } & 29 & 7.2 \\
\hline & & 100.0 \\
\hline \multicolumn{3}{|l|}{ Education } \\
\hline High school and less & 132 & 32.6 \\
\hline College diploma & 125 & 30.9 \\
\hline \multirow[t]{2}{*}{ University } & 148 & 36.5 \\
\hline & & 100.0 \\
\hline \multicolumn{3}{|l|}{ Occupation } \\
\hline Public sector & 217 & 53.6 \\
\hline Private sector & 122 & 30.1 \\
\hline \multirow[t]{2}{*}{ Self-employed and others } & 66 & 16.3 \\
\hline & & 100.0 \\
\hline \multicolumn{3}{|l|}{ Income } \\
\hline 100 to $350 \mathrm{RO}$ & 45 & 11.1 \\
\hline 351 to $600 \mathrm{RO}$ & 96 & 23.7 \\
\hline 601 to $1000 \mathrm{RO}$ & 159 & 39.3 \\
\hline 1001 to $1500 \mathrm{RO}$ & 70 & 17.3 \\
\hline \multirow[t]{2}{*}{ More than 1500 RO } & 35 & 8.6 \\
\hline & & 100.0 \\
\hline
\end{tabular}

Source: From survey response data: Note: RO is Rial Oman. 
Table 5. CETSCALE Questions. For each of the following statements that comprise the CETSCALE, respondents were asked to rate them using a 5-point scale ranging from 1-Strongly disagree to 5-Strongly Agree.

\begin{tabular}{|c|c|c|c|}
\hline Ques.\# & Question Statement & Mean & $\begin{array}{l}\text { Std. } \\
\text { Dev. }\end{array}$ \\
\hline 1 & $\begin{array}{l}\text { Omani people should always buy Omani (agricultural) products } \\
\text { instead of imports. }\end{array}$ & 3.47 & 1.17 \\
\hline 2 & $\begin{array}{l}\text { Only those Agricultural products that are unavailable in Oman } \\
\text { should be imported. }\end{array}$ & 3.67 & 1.24 \\
\hline 3 & Buy Omani locally-produced products. Keep Oman working. & 4.12 & 0.89 \\
\hline 4 & Omani products, first, last and foremost. & 3.37 & 1.18 \\
\hline 5 & Purchasing foreign (agricultural) products is un-Omani. & 2.68 & 1.27 \\
\hline 6 & $\begin{array}{l}\text { It is not right to purchase foreign (agricultural) products, because it } \\
\text { puts Omani out of jobs. }\end{array}$ & 3.17 & 1.24 \\
\hline 7 & A real Omani should always buy Omani produced products. & 3.13 & 1.23 \\
\hline 8 & $\begin{array}{l}\text { We should purchase locally produced products instead of letting } \\
\text { other countries get rich off us. }\end{array}$ & 3.68 & 1.06 \\
\hline 9 & It is always best to purchase Omani products. & 3.76 & 1.04 \\
\hline 10 & $\begin{array}{l}\text { There should be very little trading or purchasing of Agricultural } \\
\text { products from other countries unless out of necessary. }\end{array}$ & 3.38 & 1.16 \\
\hline 11 & $\begin{array}{l}\text { Oman is should not buy foreign products, because this hurts Omani } \\
\text { business and causes unemployment. }\end{array}$ & 3.18 & 1.22 \\
\hline 12 & Controls should be put on all (agricultural food) imports. & 4.00 & 1.0 \\
\hline 13 & $\begin{array}{l}\text { It may cost me in the long run but I prefer to support Omani } \\
\text { products. }\end{array}$ & 3.50 & 1.14 \\
\hline 14 & $\begin{array}{l}\text { Foreigners should not be allowed to put their products on our } \\
\text { markets. }\end{array}$ & 2.60 & 1.20 \\
\hline 15 & $\begin{array}{l}\text { Foreign products should be taxed heavily to reduce their entry into } \\
\text { Oman. }\end{array}$ & 2.90 & 1.30 \\
\hline 16 & $\begin{array}{l}\text { We should buy from foreign countries only those products that we } \\
\text { cannot obtain within our own country. }\end{array}$ & 3.60 & 1.20 \\
\hline 17 & $\begin{array}{l}\text { Omani consumers who purchase products produced in other } \\
\text { countries are responsible for putting their fellow Omani out of work. }\end{array}$ & 2.7 & 1.28 \\
\hline
\end{tabular}

Source: Survey response data.

(56.96) is significantly above the middle of the range of the CETSCALE Score $(17$ to 85$)=51$.

Following prior research [13] [26] [28] [36] [52] and [53] the CETSCALE's reliability was measured using Cronbach's alpha.

The Cronbach alpha was 0.893 , which indicates that the CETSCALE score is reliable for the Omani data since it exceeds the rule-of-thumb value of 0.70 [36] and [54].

We can therefore conclude that the Cronbach alpha value indicates the CETSCALE is reliable across the Oman sample. 
Almost all of the 17 CETSCALE statements (13 out of 17) have Likert-scale score above 3 (using a 5-point scale ranging from 1-Strongly Disagree to 5-Strongly Agree) indicating that Omani consumers in our sample are ethnocentric.

CETSCALE mean value $=56.96$ against an average of $($ range $17-85) 51$ showing that Omanis are ETHNOCENTRIC. The CETSCALE standard deviation, minimum, maximum and median was: $12.1,27,85$ and 57 respectively.

CETSCALE mean value $=56.96$ against an average of (range $17-85) 51$ showing that Omanis are ETHNOCENTRIC. The CETSCALE standard deviation, minimum, maximum and median was: $12.1,27,85$ and 57 respectively.

\subsection{Research Question Two}

Results of the attitudes of the Omani consumers to locally produced agricultural products are as presented in Table 6 below.

Table 6. Attitudes towards Omani locally produced agricultural products.

\begin{tabular}{|c|c|c|c|c|c|c|c|}
\hline \multirow{2}{*}{ No. } & \multirow{2}{*}{ Attitudinal Statement } & \multirow{2}{*}{$\mathbf{N}$} & \multirow{2}{*}{$\begin{array}{c}\text { 5-pt } \\
\text { Likert } \\
\text { Scale }\end{array}$} & $\mathrm{Bf}$ & Chkn & Tmt & Ccmber \\
\hline & & & & \multicolumn{4}{|c|}{$\%$ of the respondents } \\
\hline \multirow{5}{*}{1} & \multirow{5}{*}{$\begin{array}{l}\text { Omani locally produced } \\
\text { products are generally of } \\
\text { poorer quality than imported } \\
\text { products. }\end{array}$} & \multirow{5}{*}{405} & 1 & 45.7 & 42.7 & 44.4 & 44.2 \\
\hline & & & 2 & 26.4 & 28.6 & 24.9 & 26.2 \\
\hline & & & 3 & 11.6 & 14.1 & 17.5 & 16.5 \\
\hline & & & 4 & 8.6 & 7.7 & 7.4 & 7.7 \\
\hline & & & 5 & 7.7 & 6.9 & 5.7 & 5.4 \\
\hline \multirow{5}{*}{2} & \multirow{5}{*}{$\begin{array}{l}\text { Omani locally produced } \\
\text { products are generally } \\
\text { higher-priced than imported } \\
\text { products. }\end{array}$} & \multirow{5}{*}{405} & 1 & 8.1 & 7.4 & 18.0 & 16.8 \\
\hline & & & 2 & 11.9 & 15.8 & 29.9 & 30.9 \\
\hline & & & 3 & 15.6 & 25.7 & 30.4 & 31.9 \\
\hline & & & 4 & 37.5 & 33.1 & 14.3 & 13.1 \\
\hline & & & 5 & 26.9 & 18.0 & 7.4 & 7.4 \\
\hline \multirow{5}{*}{3} & \multirow{5}{*}{$\begin{array}{l}\text { I buy Omani locally produced } \\
\text { products wherever possible. }\end{array}$} & \multirow{5}{*}{405} & 1 & 2.7 & 1.7 & 1.7 & 2.0 \\
\hline & & & 2 & 7.9 & 6.2 & 4.0 & 4.0 \\
\hline & & & 3 & 16.8 & 16.8 & 18.3 & 18.0 \\
\hline & & & 4 & 38.3 & 39.0 & 39.0 & 39.0 \\
\hline & & & 5 & 34.3 & 36.3 & 37.0 & 37.0 \\
\hline \multirow{5}{*}{4} & \multirow{5}{*}{$\begin{array}{l}\text { These days I usually look for } \\
\text { Omani locally produced food } \\
\text { products when I am shopping } \\
\text { for food. }\end{array}$} & \multirow{5}{*}{405} & 1 & 4.0 & 3.2 & 2.2 & 2.7 \\
\hline & & & 2 & 13.6 & 11.4 & 7.7 & 7.9 \\
\hline & & & 3 & 23.2 & 23.0 & 30.9 & 30.4 \\
\hline & & & 4 & 34.8 & 36.5 & 32.6 & 32.6 \\
\hline & & & 5 & 24.4 & 25.9 & 26.7 & 26.4 \\
\hline \multirow{5}{*}{5} & \multirow{5}{*}{$\begin{array}{l}\text { People should buy food } \\
\text { products which offer them the } \\
\text { best value-for-money, whether } \\
\text { made in Oman or not. }\end{array}$} & \multirow{5}{*}{405} & 1 & 15.1 & 13.3 & 11.9 & 12.3 \\
\hline & & & 2 & 23.1 & 25.4 & 22.2 & 22.0 \\
\hline & & & 3 & 10.8 & 14.3 & 16.0 & 14.8 \\
\hline & & & 4 & 26.3 & 24.4 & 25.7 & 25.9 \\
\hline & & & 5 & 23.7 & 22.5 & 24.2 & 24.9 \\
\hline
\end{tabular}




\section{Continued}

\begin{tabular}{|c|c|c|c|c|c|c|c|}
\hline & & & 1 & 1.0 & 1.0 & 0.7 & 1.0 \\
\hline \multirow{4}{*}{6} & $\begin{array}{l}\text { People should choose the } \\
\text { Omani locally produced food }\end{array}$ & & 2 & 3.0 & 3.2 & 2.5 & 2.5 \\
\hline & products when the price and & 405 & 3 & 5.9 & 6.4 & 5.4 & 4.4 \\
\hline & $\begin{array}{l}\text { quality are as good as imported } \\
\text { food products. }\end{array}$ & & 4 & 24.2 & 23.5 & 25.4 & 25.4 \\
\hline & & & 5 & 65.9 & 65.9 & 65.9 & 66.7 \\
\hline
\end{tabular}

Source: From survey response data. (1) Note: $\mathrm{Bf}=$ Beef; Chkn = Chicken; Tmt $=$ Tomato and Ccmber $=$ Cucumber. (2) Note: Note: 1 = Strongly Disagree; 2 = Disagree; 3 = Neutral; $4=$ Agree; 5 = Strongly Agree (is the 5-point Likert scale) and $\mathrm{N}=$ Sample size.

The majority of respondents $(90.1 \%, 89.4 \%, 91.3 \%$ and $92.1 \%$ respectively for beef, chicken, tomato and cucumber) may be described as rational price-quality conscious consumers who would buy locally produced agricultural products when the price and quality of the locally produced products are as good as imported products.

This is reinforced by $(50 \%, 47 \%, 50 \%$ and $51 \%$ respectively for beef, chicken, tomato and cucumber) of the respondents who may be described as 'value for money' consumers.

This group felt that one should buy products that offer the best value for money, regardless of whether they are locally produced in Oman or imported.

Furthermore, a majority of the respondents $(72.6 \%, 75.3 \%, 76 \%$, and $76 \%$ respectively for beef, chicken, tomato and cucumber) indicated that Omani should buy Oman-locally produced products whenever possible.

With respect to quality, the majority of respondents $(72.1 \%, 71.3 \%, 69.3 \%$, $70.4 \%$ respectively for beef, chicken, tomato and cucumber) stated that Oman locally produced products were not of poorer quality.

In terms of price the views are mixed, while $64.4 \%$ and $51.1 \%$ respectively of the respondents stated that Oman beef and chicken are highly priced, only $21.7 \%$ and $20.5 \%$ respectively of the respondents thought that Oman tomatoes and cucumbers are highly priced.

In other words, aside from locally produced beef and chicken being regarded as highly priced, Oman consumers do not have a negative attitude towards Oman locally produced agricultural products in terms of quality and price. With regard to shopping for locally produced beef, chicken, tomatoes and cucumber: $59.2 \%, 62.4 \%, 59.3 \%$ and $59 \%$ of the respondents respectively indicated that they specifically look for beef, chicken, tomato and cucumber when shopping for food. Overall these results reinforce the ethnocentrism of the Oman consumers that was captured through the CETSCALE score results obtained in this study.

\subsection{Research Question Three}

Table 7 presents the attitudes of Omani consumers to "buy local" campaigns and the following trends are apparent.

The majority of respondents (90.7\%) are in favor of the government participation in encouraging Omanis to buy locally produced food products, compared to 
Table 7. Attitudes to "Buy Local" campaigns.

\begin{tabular}{|c|c|c|c|c|c|c|c|}
\hline No. & Attitudinal Statement & $\mathbf{N}$ & 1 & 2 & 3 & 4 & 5 \\
\hline & & & \multicolumn{5}{|c|}{$\%$ of the respondents } \\
\hline 1 & $\begin{array}{l}\text { Oman government should } \\
\text { encourage Omanis to buy locally } \\
\text { produced food products. }\end{array}$ & 405 & 1.2 & 1.5 & 6.7 & 39.3 & 51.4 \\
\hline 2 & $\begin{array}{l}\text { Oman industry should encourage } \\
\text { Omanis to buy locally produced } \\
\text { food products. }\end{array}$ & 405 & 1.2 & 2.0 & 7.9 & 41.7 & 47.2 \\
\hline 3 & $\begin{array}{l}\text { Buying Omani locally produced } \\
\text { food products will help Oman } \\
\text { economy }\end{array}$ & 405 & 0.7 & 3.2 & 9.9 & 40.2 & 45.9 \\
\hline 4 & $\begin{array}{l}\text { The "Origin Oman" or "Buy } \\
\text { Local" campaign is successful in } \\
\text { persuading Omanis to think } \\
\text { about changing their food shop- } \\
\text { ping habits. }\end{array}$ & 405 & 5.7 & 8.1 & 22.7 & 34.8 & 28.6 \\
\hline 5 & $\begin{array}{l}\text { The government should do more to } \\
\text { promote Omani locally } \\
\text { produced food products (such as } \\
\text { Beef and Chicken) locally and } \\
\text { overseas }\end{array}$ & 405 & 1.7 & 2.0 & 5.9 & 40.2 & 50.1 \\
\hline 6 & $\begin{array}{l}\text { Buying Omani locally produced } \\
\text { food products creates work } \\
\text { opportunities in Oman }\end{array}$ & 405 & 2.0 & 3.2 & 20.2 & 40.5 & 34.3 \\
\hline 7 & $\begin{array}{l}\text { I feel the personal contribution that } \\
\text { I might make by buying Omani } \\
\text { locally produced food } \\
\text { products is insignificant }\end{array}$ & 405 & 31.4 & 27.4 & 17.5 & 15.8 & 7.9 \\
\hline 8 & $\begin{array}{l}\text { The agricultural industry should be } \\
\text { more competitive }\end{array}$ & 405 & 0.0 & 2.0 & 6.4 & 42.5 & 49.1 \\
\hline 9 & $\begin{array}{l}\text { Oman should regulate and when } \\
\text { necessary should restrict the } \\
\text { inflow of imported food products } \\
\text { that compete with locally } \\
\text { produced food products }\end{array}$ & 405 & 7.9 & 16.8 & 23.2 & 29.1 & 23.0 \\
\hline
\end{tabular}

Source: From survey response data. Note: $1=$ Strongly Disagree; $2=$ Disagree; $3=$ Neutral; $4=$ Agree; $5=$ Strongly Agree (is the 5-point Likert scale) $\mathrm{N}=$ Sample size.

(88.9\%) who said the industry should do it. However, the difference does not seem to be significant, which seems to suggest the need for both the government and the industry to work together on this. While the majority of respondents ( $90.7 \%$ and $88.9 \%$ respectively) are in favor of the government and industry support of "Buy Local" campaign, only $63.4 \%$ of the respondents agreed that the "Buy Local" campaign have been successful in persuading Omanis to think about changing their food shopping habits. In other words, $36.6 \%$ of the respondents were of the view that the "Buy Local" campaign was unsuccessful.

This view is overwhelmingly supported by $90.3 \%$ of the respondents who be- 
lieve that the government should do more to promote Omani locally produced food products such as Beef and Chicken.

With regard to job opportunities, $74.8 \%$ thought that buying Omani locally produced food products would create work opportunities in Oman. This view is supported by $86.1 \%$ of respondents who are of the opinion that buying Omani locally produced food products will help Oman economy.

A majority of respondents (58.8\%) felt that their personal contribution that they might make by buying Omani locally produced food products is significant. Only (23.7\%) viewed their personal contribution as being insignificant. Respondents also indicated overwhelmingly (91.6\%) that the Oman agricultural industry must be more competitive.

With respect to restriction on the inflow of imports, only 51.2 of respondents thought Oman should regulate and when necessary restrict the inflow of imported food products that compete with locally produced food products.

In summary, looking at these results, there appears to be a strong support by Omani consumers for the "Buy Local" campaign. At the same time consumers wants the agricultural industry to be competitive. Furthermore, Omani consumers understand that buying locally produced food products would create jobs in Oman and help the economy.

\section{Conclusion and Policy Implications}

This study investigates the consumer ethnocentrism of Omanis. This information is needed, firstly, to support the Omani government effort to diversify the economy and secondly, to generate information that might be potentially useful to investors in the agricultural and fisheries sector of the Oman economy.

The Oman government has embarked on the so called Vision 2020 Strategy which lays down strategies to diversify the Oman economy beyond the petroleum sector. The Vision 2020 Strategies puts emphasis on sectors such as agriculture and fisheries to contribute more to the Oman economy. For the agricultural sector to fulfill its obligations under the Vision 2020, it is important, among other things, to promote locally-produced agricultural commodities such as beef, chicken and vegetables-commodities that Oman has some comparative advantage in production. However, this may not be easy, because Oman is an open economy and is therefore a part of the globalized world. According to [28], one outcome of globalization is increased competition between local and foreign firms in both foreign and local markets. Increased competition leads to greater availability of both locally-produced and imported agricultural food commodities. Therefore, Omani consumers are facing increasing variety of buying options. In this competitive business environment, promoting locally-produced commodities successfully require businesses and the government to understand the attitudes of consumers, especially on how they choose between locally-produced products and products of foreign origin. Therefore, investigating consumer ethnocentrism of Omani consumers is a vital step towards forming a 
better understanding of the way in which individual consumers in Oman draw comparisons between domestic and foreign products, as well as the reasons that lead them to do so. Results on the extent of Consumer Ethnocentrism in Oman indicated that Oman consumers are ethnocentric. This is good news to both policy makers and businesses, because as pointed by [13] strongly ethnocentric consumers are the ones that are likely to support the "Buy Locally-produced products" campaigns. Therefore, the "Buy Locally-produced products" campaigns have the opportunity to succeed because Omani consumers will support such campaigns. The majority of Omani have positive attitude towards "locally-produced products. Omani consumers would buy locally produced agricultural products when the price and quality of the locally produced products are as good as imported products, and these results are consistent with the findings by [36] on Ghanaian consumers. While the majority of consumers believe that Oman locally produced products are of good quality, when it comes to price, consumers think Oman beef and chicken are highly priced. Based on these results, we can conclude that, aside from locally produced beef and chicken being regarded as highly priced, Oman consumers do not have a negative attitude towards Oman locally produced agricultural products in terms of quality and price.

These are very important insights, which seem to suggest that, for locally produced products to be successful in the market place, they should be of comparable quality to imported products. Furthermore, even though Omani consumers are ethnocentric, still they are of the opinion that current prices of beef and chicken are too high.

Regarding the views of Omani consumers towards "buy local" campaigns, results indicate that Oman consumers believe the "Buy Local" campaigns have been successful in persuading Omani to think about changing their food shopping habits in favor of local products. With respect to job opportunities, and the economy in general, Omani consumers believe that buying locally produced food products would create work opportunities in Oman and hence would help boost the Oman economy.

Looking at these results therefore, there appears to be a strong support by Omani consumers for the "Buy Local" campaigns. At the same time, consumers want the agricultural industry to be competitive. This study is the first of its kind in the GCC region; therefore, it contributes to the understanding of the effects of consumer ethnocentrism and to the academic literature in the area of consumer evaluations of locally produced agricultural products. Furthermore, this study has implications for farmers, businesses and the government. For example, it is found that Omani consumers will buy locally produced products, not just because they are locally-produced, but because the products are of comparable quality and price as imported products, compels farmers, business and the government to pay attention to the quality of local products. At policy level, it is clear from the study that the "Buy Local" campaigns are perceived to be not fully 
successful; Omani consumers think more needs to be done jointly by the government and the industry.

\section{References}

[1] Kaynak, E. and Kara, A. (2002) Consumer Perceptions of Foreign Products: An Analysis of Product-Country Images and Ethnocentrism. European Journal of Marketing, 36, 928-949. https://doi.org/10.1108/03090560210430881

[2] Kucukemiroglu, O. (1999) Market Segmentation by Using Consumer Lifestyle Dimensions and Ethnocentrism. European Journal of Marketing, 33, 470-487.

https://doi.org/10.1108/03090569910262053

[3] Al-Sulaiti, K.I. and Baker, M.J. (1998) Country-of-Origin Effects: A Literature Review. Marketing Intelligence and Planning, 16, 150-199.

https://doi.org/10.1108/02634509810217309

[4] Bhaskaran, S. and Sukumaran, N. (2007) Contextual and Methodological Issues in COO Studies. Marketing Intelligence and Planning, 25, 66-81. https://doi.org/10.1108/02634500710722407

[5] Ahmed, Z.U., Johnson, J.P., Yang, X., Fatt, C.K., Teng, H.S. and Boon, L.C. (2004) Does Country of Origin Matter for Low-Involvement Products? International Marketing Review, 21, 102-120. https://doi.org/10.1108/02651330410522925

[6] Monroe, K. and Krishnan, R. (1985) The Effect of Price on Subjective Product Evaluations. In: Jacoby, J. and Olson, J., Eds., Perceived Quality: How Consumers View Stores and Merchandise, Lexington Books, Boston, MA, 209-232.

[7] Rao, A. and Monroe, K. (1989) The Effect of Price, Brand, Name and Store Name on Buyers' Perceptions of Product Quality: An Integrative Review. Journal of Marketing Research, 26, 351-358. https://doi.org/10.2307/3172907

[8] Jacoby, J., Szybillo, G.J. and Busato-Schach, J. (1977) Information Acquisition Behaviour in Brand Choice Situations. Journal of Consumer Research, 3, 209-216. https://doi.org/10.1086/208669

[9] Zeithaml, V.A. (1988) Consumer Perceptions of Price, Quality and Value: A Means-End Model and Synthesis of Evidence. Journal of Marketing, 52, 2-22. https://doi.org/10.2307/1251446

[10] Altinaş, M.H. and Tokol, T. (2007) Cultural Openness and Consumer Ethnocentrism: An Empirical Analysis of Turkish Consumers. Marketing Intelligence and Planning, 25, 308-325. https://doi.org/10.1108/02634500710754565

[11] Bawa, A. (2004) Consumer Ethnocentrism: CETSCALE Validation and Measurement of Extent. Vikalpa, 29, 43-57. https://doi.org/10.1177/0256090920040304

[12] Sumner, G.A. (1906) Folkways. Ginn Custom Publishing, New York.

[13] Shimp, T.A. and Sharma, S. (1987) Consumer Ethnocentrism: Construction and Validation of the CETSCALE. Journal of Marketing Research, 24, 280-289. https://doi.org/10.2307/3151638

[14] Wall, M. and Heslop, L.A. (1986) Consumer Attitudes toward Canadian-Made versus Imported Products. Journal of the Academy of Marketing Science, 14, 27-36. https://doi.org/10.1007/BF02722154

[15] Watson, J. and Wright, K. (2000) Consumer Ethnocentrism and Attitudes toward Domestic and Foreign Products. European Journal of Marketing, 34, 1149-1166. https://doi.org/10.1108/03090560010342520

[16] Insch, G.S. and McBride, J.B. (2004) The Impact of Country-of-Origin Cues on 
Consumer Perceptions of Product Quality: A Binational Test of the Decomposed Country-of-Origin Construct. Journal of Business Research, 57, 256-265. https://doi.org/10.1016/S0148-2963(02)00323-5

[17] Ahmed, S.A., d'Astous, A. and El-Adraoui, M. (1994) Country-of-Origin Effects on Purchasing Managers' Product Perceptions. Industrial Marketing Management, 23, 323-332. https://doi.org/10.1016/0019-8501(94)90048-5

[18] Cordell, V.V. (1991) Competitive Context and Price as Moderators of Country of Origin Preferences. Journal of the Academy of Marketing Science, 19, 123-128. https://doi.org/10.1007/BF02726004

[19] Leonidou, L.C., Hadjimarcou, J., Kaleka, A. and Stamenova, G.T. (1999) Bulgarian Consumers' Perceptions of Products Made in Asia Pacific. International Marketing Review, 16, 126-142. https://doi.org/10.1108/02651339910267817

[20] Ahmed, S.A. and d'Astous, A. (2008) Antecedents, Moderators and Dimensions of Country-of-Origin Evaluations. International Marketing Review, 25, 75-106. https://doi.org/10.1108/02651330810851890

[21] Acharya, C. and Elliott, G. (2003) Consumer Ethnocentrism, Perceived Product Quality and Choice: An Empirical Investigation. Journal of International Consumer Marketing, 15, 87-114. https://doi.org/10.1300/J046v15n04_05

[22] Shankarmahesh, M.N. (2006) Consumer Ethnocentrism: An Integrative Review of Its Antecedents and Consequences. International Marketing Review, 23, 146-172. https://doi.org/10.1108/02651330610660065

[23] Herche, J. (1992) A Note on the Predictive Validity of the CETSCALE. Journal of the Academy of Marketing Science, 20, 261-264. https://doi.org/10.1007/BF02723413

[24] De Ruyter, K., van Birgelen, M. and Wetzels, M. (1998) Consumer Ethnocentrism in International Services Marketing. International Business Review, 7, 185-202. https://doi.org/10.1016/S0969-5931(98)00005-5

[25] Kwak, H., Jaju, A. and Larsen, T. (2006) Consumer Ethnocentrism Offline and Online: The Mediating Role of Marketing Efforts and Personality Traits in the United States, South Korea, and India. Journal of the Academy of Marketing Science, 34, 367-385. https://doi.org/10.1177/0092070304270140

[26] Sharma, S., Shimp, T. and Shin, J. (1995) Consumer Ethnocentrism: A Test Antecedents and Moderators. Journal of the Academy of Marketing Science, 23, 26-37. https://doi.org/10.1007/BF02894609

[27] Luque-Martinez, T., Ibanez-Sapata, J. and del Barrio-Garcia, S. (2000) Consumer Ethnocentrism Measurement: An Assessment of the Reliability and Validity of the CETSCALE in Spain. European Journal of Marketing, 34, 1353-1373. https://doi.org/10.1108/03090560010348498

[28] Netemeyer, M., Durvasula, S. and Lichtenstein, D. (1991) A Cross-National Assessment of the Reliability and Validity of the CETSCALE. Journal of Marketing Research, 28, 320-327. https://doi.org/10.2307/3172867

[29] Orth, U.R. and Firbasovā, Z. (2003) The Role of Consumer Ethnocentrism in Food Product Evaluation. Agribusiness, 19, 137-153. https://doi.org/10.1002/agr.10051

[30] Javalgi, R.G., Khare, V.P., Gross, A.C. and Scherer, R.F. (2005) An Application of the Consumer Ethnocentrism Model to French Consumers. International Business Review, 14, 325-344. https://doi.org/10.1016/j.ibusrev.2004.12.006

[31] Caruana, A. and Magri, E. (1996) The Effect of Dogmatism and Social Class Variables on Consumer Ethnocentrism in Malta. Marketing Intelligence and Planning, 
14, 39-44. https://doi.org/10.1108/02634509610121569

[32] Supphellen, M. and Rittenburg, T.L. (2001) Consumer Ethnocentrism when Foreign Products Are Better. Psychology and Marketing, 18, 907-927. https://doi.org/10.1002/mar.1035

[33] Huddleston, P., Good, L.K. and Stoel, L. (2001) Consumer Ethnocentrism, Product Necessity and Polish Consumers' Perceptions of Quality. International Journal of Retail and Distribution Management, 29, 236-246. https://doi.org/10.1108/09590550110390896

[34] Saffu, K. and Walker, J.H. (2005) An Assessment of the Consumer Ethnocentric Scale (CETSCALE) in an Advanced and Transitional Country: The Case of Canada and Russia. International Journal of Management, 22, 556-571.

[35] Shoham, A. and Brenčič, M.M. (2003) Consumer Ethnocentrism, Attitudes and Purchase Behavior: An Israeli Study. Journal of International Consumer Marketing, 15, 67-86. https://doi.org/10.1300/J046v15n04_04

[36] Saffu, K. and Walker, J.H. (2006) The Country-of-Origin Effect and Consumer Attitudes to "Buy Local" Campaign. Journal of African Business, 7, 183-199.

https://doi.org/10.1300/J046v15n04_04

[37] Kavak, B. and Gumusluoglu, L. (2007) Segmenting Food Markets: The Role of Ethnocentrism and Lifestyle in Understanding Purchasing Intentions. International Journal of Market Research, 49, 71-94. https://doi.org/10.1177/147078530704900108

[38] Lindquist, J.D., Vida, I., Plank, R.E. and Fairhurst, A. (2001) The Modified CETSCALE: Validity Tests in the Czech Republic, Hungary, and Poland. International Business Review, 10, 505-516. https://doi.org/10.1016/S0969-5931(01)00030-0

[39] Douglas, S.P. and Nijssen, E.J. (2003) On the Use of "Borrowed" Scales in Cross-National Research. International Marketing Review, 20, 621-642. https://doi.org/10.1108/02651330310505222

[40] Hamin, H. and Elliott, G. (2006) A Less-Developed Country Perspective of Consumer Ethnocentrism and "Country of Origin Effects": Indonesian Evidence. Asia Pacific Journal of Marketing and Logistics, 18, 79-92. https://doi.org/10.1108/13555850610658246

[41] Philp, K. and Brown, L. (2003) Does Consumer Ethnocentrism Impact on Australian Food Buying Behavior. Journal of New Business Ideas and Trends, 1, 21-43.

[42] Chambers, S., Lobb, A., Butler, L., Harvey, K. and Traill, B.W. (2007) Local, National and Imported Foods: A Qualitative Study. Appetite, 49, 208-213. https://doi.org/10.1016/j.appet.2007.02.003

[43] Born, B. and Purcell, M. (2006) Avoiding the Local Trap: Scale and Food Systems in Planning Research. Journal of Planning Education and Research, 26, 195-207. https://doi.org/10.1177/0739456X06291389

[44] Saffu, K., Walker, J.H. and Mazurek, M. (2010) The Role of Consumer Ethnocentrism in a Buy National Campaign in a Transitioning Country: Some Evidence from Slovakia. International Journal of Emerging Markets, 5, 203-226. https://doi.org/10.1108/17468801011031829

[45] Lumb, R. and Kuperman, J.C. (2012) Ethnocentrism in the U.S.: An Examination of CETSCALE Stability from 1994 to 2008. Academy of Marketing Studies Journal, 16, 99-110.

[46] Sandeep, S. and Swati, K. (2013) Ethnocentrism and "Made in Tags" Go Hand in Hand for Indian Youths "CETSCALE Validation and Dimensionality Assessment". 
European Journal of Business and Management, 5, 198-211.

[47] Durvasula, S., Andrews, J. and Netemeyer, R. (1997) A Cross-Cultural Comparison of Consumer Ethnocentrism in the United States and Russia. Journal of International Consumer Marketing, 9, 73-93. https://doi.org/10.1300/J046v09n04_05

[48] Herche, J. (1990) The Measurement of Consumer Ethnocentrism: Revisiting the CETSCALE. In: Dunlop, J. and Cullowhee, Eds., Developments in Marketing Science, Academy of Marketing Science, Vol. 23, 37-375.

[49] Herche, J. (1994) Ethnocentric Tendencies, Marketing Strategy and Import Purchase Behaviour. International Marketing Review, 11, 4-16. https://doi.org/10.1108/02651339410067012

[50] Cameron, R. and Elliot, G. (1998) The 'Country-of-Origin Effect' and Consumer Attitudes to 'Buy Local' Campaigns: Australian Evidence. Australasian Marketing Journal, 6, 39-50. https://doi.org/10.1016/S1441-3582(98)70248-4

[51] Bush, A.J. and Hair, J.F. (1985) An Assessment of the Mall Intercept as a Data Collection Method. Journal of Marketing Research, 22, 158-167.

https://doi.org/10.2307/3151361

[52] Mulye, R., Rickard, J., and Higginson, T. (1997) Some Evidence of Consumer Ethnocentrism in Australia. Journal of Management \& Organization, 3, 1-11. https://doi.org/10.1017/S1833367200005861

[53] Hult, G.T.M., Keillor, B.D. and Lafferty, B.A. (1999) A Cross-National Assessment of Social Desirability Bias and Consumer Ethnocentrism. Journal of Global Marketing, 12, 29-43. https://doi.org/10.1300/J042v12n04_03

[54] Nunnally, J. (1978) Psychometric Theory. 2nd Edition, McGraw-Hill, New York. 